\title{
PENINGKATAN HASIL BELAJAR MATERI MENDESKRIPSIKAN KONDISI FISIK WILAYAH DAN PENDUDUK MELALUI MODEL PEMBELAJARAN “G TO G INVESTIGATION” DI SMP NEGERI 2 DONGKO
}

\author{
Mamik Utami Harini, S.Pd ${ }^{1)}$ \\ 1) SMP Negeri 2 Dongko \\ mamikutami1970@yahoo.com
}

\begin{abstract}
ABSTRAK: Luasnya materi dari KD 1.1 seharusnya bukan merupakan masalah bagi siswa-siswa SMP Negeri 2 Dongko, karena diperpustakaan telah menyediakan buku-buku cetak mata pelajaran IPS. Selain buku-buku rujukan di perpustakaan, setiap siswa juga mempunyai buku pendamping mata pelajaran IPS. Akan tetapi keengganan dalam membaca ini cukup menghambat pencapaian hasil yang optil. Untuk itu peneliti melakukan penelitian tindakan kelas dengan judul Peningkatan Hasil Belajar Materi Mendeskripsikan Kondisi Fisik Wilayah Dan Penduduk Melalui Model Pembelajaran "G to G Investigation" Pada Kelas VIII A Semester 1 Di SMP Negeri 2 Dongko. Penelitian ini dilakukan dengan menggunakan tahap-tahap pelaksanaan yang didalamnya terdapat empat tahap kegiatan. Penelitian ini memilih kelas VIII A dengan alasan bahwa kegiatan pembelajaran sehari-hari pada saat kelas VII kelas VIII A ini merupakan kelas yang masih rendah hasil belajarnya. Adapun Instrumen yangdalam penelitian adalah tes tulis pilihan ganda sejumlah 20 butir soal yang pelaksanaannya pada akhir pertemuan ke 2 . Dari hasil penelitian dapat diketahui peingkayan keberhasilan siswa, pada saat siklus 1 persentase ketuntasan adalah $75.00 \%$ meningkat menjadi $90,63 \%$ pada saat siklus 2. Demikian pula dengan nilai rata-rata kelas VIII A pada saat siklus 1 adalah 71,5 dan meningkat menjadi 78,44 pada siklus 2.
\end{abstract}

Kata kunci : Prestasi, G to G Investigation.

ABSTRACT: By applying KTSP the time for teaching learning IPS (social study) is reduced. Actually it is not the problem for the students of SMPN 2 Dongko, because the library has provided with many book references. But the students tend to reluctant in reading some material. That is why the achievement for this material is not good for years. That is why the writer hold the research by applying the model $G$ to $G$ Investigation in VIII A semester 1. This research hold in 2 cycles 4 stages. The instrument used is multiple choice test consist of 20 item taking after the second meeing. After the research it can be know the development of students' achievemet. The percentage of students mastery has increased from $75.00 \%$ in cycle 1 to be 90,63\% in cycle 2. The average achivement has also incresased from 71,5 in cycle 1 into 78,44 in cycle

Keywords: Achievement, $G$ to $G$ Investigation

\section{PENDAHULUAN}

Mata pelajaran Ilmu Pengetahuan Sosial (IPS) adalah mata pelajaran yang termasuk dalam kelompok mata pelajaran ilmu pengetahuan dan teknologi; Sedangkan ruang lingkup mata pelajaran IPS ini meliputi aspek-aspek sebagai berikut: 1) Manusia, Tempat, dan Lingkungan 2) Waktu, Keberlanjutan, dan Perubahan, 3)Sistem Sosial dan 
Budaya dan 4) Perilaku Ekonomi dan Kesejahteraan. Ruang lingkup tersebut kalau kalau dijabarkan dalam standar kompetensi maka materi IPS menjadi sangat luas.

Salah satu Kompetensi Dasar yang mempunyai cakupan luas adalah KD 1.1 Mendeskripsikan kondisi fisik wilayah dan penduduk yang diberikan di kelas VIII semester 1. KD ini mempunyai 4 indikator yakni: 1) Letak geografis Indonesia (letak geografis dan letak astronomis), 2) Musim di Indonesia, 3) Persebaran flora dan fauna Indonesia dan kaitannya dengan pembagian wilayah Wallacea dan Weber, 4) Persebaran jenis tanah di Indonesia.

Luasnya materi dari KD 1.1 ini seharusnya bukan merupakan hal yang memberatkan. Karena diperpustakaan telah menyediakan buku-buku cetak mata pelajaran IPS.. Selain buku-buku rujukan di perpustakaan, setiap siswa juga mempunyai buku pendamping mata pelajaran IPS. Ada juga peta-peta yang bisa digunakan sebagai media pembelajaran yang sanga pendukung dalam pencapaian hasil belajar siswa kelas VIII.

Akan tetapi karakter siswa-siswa SMP Negeri 2 Dongko yang enggan membaca ini cukup menghambat pencapaian pemahaman mereka terhadap materi ajar. Apalagi cakupan materi Kompetensi Dasar ini cukup luas. Dan ternyata waktu penyajian yang hanya 4 X 45 menit rupa-rupanya masih kurang bagi para siswa. Sehingga membuat hasil belajar siswa dari tahun ke tahun untuk KD 1.1 tidak memuaskan. Banyak siswa yang tidak bisa menuntaskan KD ini. Guru sering mengadakan kegiatan remidial

Karena adanya fakta seperti ini maka maka peneliti berupaya untuk mencari jalan keluar agar mereka bisa mendapatkan hasil yang maksimal. Dalam pembelajaran kooperatif ada banyak model pembelajaran dengan harapan dapat mengatasi hambatan dari siswa yang enggan membaca dengan berkerja secara berkelompok. Sebagaimana prinsip dasar dalam model pembelajaran kooperatif seperti yang diungkapkan oleh Johnson \& Johnson (dalam Isjoni, 2009: 17), sebagaimana berikut:

1) Setiap anggota kelompok (siswa) bertanggung jawab atas segala sesuatu yang dikerjakan dalam kelompoknya.

2) Setiap anggota kelompok (siswa) harus mengetahui bahwa semua anggota kelompok mempunyai tujuan yang sama.

3) Setiap anggota kelompok (siswa) harus membagi tugas dan tanggung jawab yang sama di antara anggota kelompoknya.

4) Setiap anggota kelompok (siswa) akan dikenai evaluasi.

5) Setiap anggota kelompok (siswa) berbagi kepemimpinan dan membutuhkan keterampilan untuk belajar bersama selama proses belajarnya.

6) Setiap anggota kelompok (siswa) akan diminta mempertanggungjawabkan secara individual materi yang ditangani dalam kelompok kooperatif.

Karena Kompetensi Dasar Mendeskripsikan wilayah dan penduduk Indonesia adalah Kompetensi Dasar pertama yang disajikan pada kelas VIII semester 1 maka pertimbangan peneliti dalam memilih subyek penelitian adalah berdasarkan hasil uji 
kompetensi yang terakhir dilakukan sebelum UKK pada siswa kelas VII. Dan pada tahun pelajaran 2019/2010, ternyata kelas VII A adalah kelas yang mencapai ketuntasan secara klasikal yang paling rendah dibandingkan dengan 3 kelas lainnya. Dari siswa 32 hanya $56,25 \%$ yang bisa mencapai nilai KKM, sedangkan sisanya $43,75 \%$ tidak bisa mencapai KKM. Demikian juga dengan perolehan nilai rata-rata kelas yang cukup rendah, yakni hanya 65,00. Ini adalah dan nilai rata-rata kelas yang terendah. Sehingga pada saat itu guru pengampu harus mengadakan kegiatan remedial agar mereka bisa mencapai ketuntatasan minimal.

Adanya kenyataan bahwa kompetensi ini masih rendah hasil, hal ini berarti menunjukan bahwa pembelajaran yang kurang berhasil. Ketidakberhasilan ini dimungkinkan karena model pembelajaran yang digunakan kurang tepat, maka peneliti sebagai guru kelas VIII merasa terpanggil untuk mencari model pembelajaran yang belum pernah dilakukan agar kegiatan pembelajaran menjadi berkesan bagi mereka. Dengan harapan apabila kegiatan pembelajaran berkesan maka pengetahuan yang diperoleh akan membekas dalam benak meraka, dan akan berimbas pada saat uji kompetensi.

Salah satu alternatif yang dilakukan peneliti adalah dengan menggunakan salah satu model dalam pembelajaran kooperatif dengan harapan dapat lebih meningkatkan hasil belajar siswa dalam mempelajari KD 1.1. Agar lebih menarik perhatian siswa maka dalam kegiatan penelitian ini peneliti menerapkan model pembelajaran yang disebut $\mathrm{G}$ to G Investigation.

Berdasarkan uraian diatas peneliti melakukan penelitian tindakan kelas dengan judul Peningkatan Hasil Belajar Materi Mendeskripsikan Kondisi Fisik Wilayah Dan Penduduk Melalui Model Pembelajaran "G to G Investigation" Pada Kelas VIII A Semester 1 Tahun Pelajaran 2010/2011 Di SMP Negeri 2 Dongko. Permasalahan yang dikaji dalam penelitian tindakan kelas ini dapat dirumuskan sebagai berikut: "Bagaimanakah peningkatan hasil belajar materi mendeskripsikan kondisi fisik wilayah dan penduduk melalui model pembelajaran "G to G Investigation" pada kelas VIII A Semester 1 Tahun Pelajaran 2010/2011 Di SMP Negeri 2 Dongko?

Tujuan penelitian ini untuk memberikan gambaran secara menyeluruh dan obyektif tentang peningkatan hasil belajar mendeskripsikan kondisi fisik wilayah dan penduduk melalui model pembelajaran "G to G Investigation" pada kelas VIII A semester 1 tahun pelajaran 2010/2011 Di SMP Negeri 2 Dongko. Penelitian tindakan kelas ini memberikan manfaat yang besar 1) Bagi siswa, penelitian ini dapat menciptakan suasana pembelajaran yang lebih menarik dan menyenangkan pada pembelajaran IPS dan meningkatkan hasil belajar siswa dalam mengikuti proses pembelajaran IPS. 2) Bagi guru, penelitian ini dapat Merangsang penelitian kelas lain sehingga meningkatkan kinerja guru dan meningkatkan kreatifitas guru di sekolah dalam pembelajaran IPS agar diperoleh hasil belajar yang optimal, 3) Bagi sekolah, penelitian ini dapat memberikan kontribusi bagi sekolah dalam rangka memperbaiki pembelajaran di dalam maupun luar 
kelas, sehingga akan meningkatkan kualitas proses pembelajaran dan memperkaya variasi pembelajaran di SMP Negeri 2 Dongko.

\section{KAJIAN PUSTAKA}

Hasil belajar adalah gabungan dari 2 kata yaitu kata hasil dan belajar. Menurut WJS. Poerwodarminto dalam Kamus Besar Bahasa Indonesia (2003:343) kata hasil berarti sesuatu yang diadakan (dibuat, dijadikan) akibat usaha. Sedangkan kata belajar ada beberapa ahli dalam dunia pendidikan yang telah memberikan definisi belajar. Morgan (Ngalim Purwanto, 2002: 84) berpendapat bahwa belajar adalah setiap perubahan yang relatif menetap dalam tingkah laku yang terjadi sebagai suatu hasil dari latihan atau pengalaman. Sementara itu Slameto menyatakan bahwa belajar ialah suatu proses usaha yang dilakukan seseorang untuk memperoleh suatu perubahan tingkah laku yang baru secara keseluruhan, sebagai hasil pengalamannya sendiri dalam interaksi dengan lingkungannya (Slameto, 2010: 10). Hasil belajar merupakan kemampuan yang diperoleh individu setelah proses belajar berlangsung, yang dapat memberikan perubahan tingkah laku baik pengetahuan, pemahaman, sikap dan keterampilan siswa sehingga menjadi lebih baik dari sebelumnya. Tentang hasil belajar ini Nana Sudjana (2005: 5) berpendapat bahwa hasil belajar siswa pada hakikatnya adalah perubahan tingkah laku dan sebagai umpan balik dalam upaya memperbaiki proses belajar mengajar. Tingkah laku sebagai hasil belajar dalam pengertian luas mencakup bidang kognitif, afektif dan psikomotorik. Syaiful Bahri Djamarah (1996:23) mengungkapkan hasil belajar adalah hasil yang diperoleh berupa kesan-kesan yang mengakibatkan perubahan dalam diri individu sebagai hasil dari aktivitas dalam belajar. Eko Putro Widoyoko (2009:1), mengemukakan bahwa hasil belajar terkait dengan pengukuran, kemudian akan terjadi suatu penilaian dan menuju evaluasi baik menggunakan tes maupun non-tes. Pengukuran, penilaian dan evaluasi bersifat hirarki. Evaluasi didahului dengan penilaian (assessment), sedangkan penilaian didahului dengan pengukuran.

Model pembelajaran "G to G Investigation" adalah model pembelajarn yang dalam langkah-langkahnya mengadopsi model pembelajaran kooperatif "Galery Walk". Ditinjau dari segi bahasa "Galery Walk" adalah frase yang terdiri dari kata "galery " dan "walk". Kata "galery" mempunyai makna pameran yakni memperkenalkan produk, karya atau gagasan kepada khalayak ramai. Sedangkan kata "walk" mempunyai arti berjalan. Gallery Walk menurut Silberman (2007: 264) adalah Galeri belajar adalah suatu cara untuk menilai dan untuk merayakan apa yang sudah mereka pelajar. Sedangkan menurut Francek dalam Journal of College Science Teaching (2006:27), "Gallery walk is a discussion technique that gets students out of their chairs and actively involved in synthesizing important science concepts, writing, and public speaking. The technique also cultivates listening and team building skills. Apabila diterjemahkan dapat berarti bahwa"Gallery walk adalah sebuah teknik diskusi yang membuat siswa bangkit dari kursinya dan terlibat secara aktif dalam merumuskan konsep pengetahuan, tulisan atau 
pembicaraan publik yang penting. Teknik ini juga membangun kemampuan menyimak dan pembentukan tim.

Sedangkan menurut Uno (2011: 50) model pembelajaran "Gallery walk" disebut juga dengan istilah keliling kelompok yang mempunyai tujuan agar masing-masing anggota kelompok mendapat kesempatan untuk memberikan kontribusi mereka dan mendengarkan pandangan atau pemikiran anggota lainnya. Selanjutnya disebutkan langkah-langkah penerapan model pembelajaran Gallery Walk sebagaimana berikut:

1) Peserta dibagi dalam beberapa kelompok.

2) Kelompok diberi kertas plano/ flip chart.

3) Tentukan topik/tema pelajaran.

4) Hasil kerja kelompok ditempel di dinding.

5) Masing-masing kelompok berputar mengamati hasil kerja kelompok lain. :

6) Salah satu wakil kelompok menjawab setiap apa yang ditanyakan oleh kelompok lain

7) Koreksi bersama-sama.

8) Klarifikasi dan penyimpulan.

Model pembelajaran "G to G Investigation" adalah singkatan dari "Group to Group Investigation". Invetigation yang berasal dari kata "to investigate" yang dapat diartikan memeriksa, meneliti atau mencari informasi. Sedangkan "group to group" dapat diterjemahkan antar kelompok. Sesuai dengan namanya maka setiap siswa akan serangkaian kegiatan secara berkelompok untuk melakukan kegiatan "investigation" atau pencarian informasi dari kelompok lain. Kegiatan "investigation" sebenarnya sudah mulai mereka lakukan pada pertemuan pertama yakni "investigation" dalam kelompok dengan mencari informasi pada materi yang diberikan dan akan berlanjut pada pertemuan kedua dimana kegiatan "Group to Group Investigation" akan diterapkan. Dalam kegiatan ini tugas anggota kelompok ada 2 macam yang bertugas menjadi pemberi informasi 3 lainnya bertugas mencari informasi atau investigation.

Karena jumlah siswa cukup banyak, 32 siswa maka siswa akan dibagi menjadi 2 kelompok besar A dan B. Pembagian siswa menjadi 2 kelompok besar ini adalah untuk memudahkan peneliti dalam melakukan pengawasan dan pembagian tugas. Masingmasing kelompok A dan B terdiri dari 4 kelompok kecil. Setiap kelompok kecil akan beranggotakan 4 siswa. Selanjutnya kelompok kecil ini akan menerima 1 sub indikator. Karena cakupan materi perindikator cukup luas untuk memudahkan siswa dalam melakukan investigation (pencarian informasi) dalam kelompok maka peneliti memecah 1 indikator menjadi 2 subindikator.

\section{METODE PENELITIAN}

Peneliti adalah penelitian tindakan kelas (PTK). Peneltian Tindakan Kelas (PTK) merupakan penelitian oleh guru, dengan memanfaatkan interaksi, partisipasi dan kolaborasi antar peneliti dengan siswa (Depdiknas, 2004:1). Adapun tujuan dari PTK 
adalah untuk memperbaiki proses pembelajaran. Fokus penelitian terletak pada tindakan yang diambil oleh peneliti yang kemudian diujicobakan dan dievaluasi apakah tindakan itu dapat memecahkan masalah pembelajaran yang dihadapi. Penelitian ini dilakukan dengan menggunakan tahap-tahap pelaksanaan yang didalamnya terdapat empat tahap kegiatan yaitu: perencanaan (planning), pelaksanaan tindakan (acting), observasi (observing) dan refleksi (reflecting), (Kurt Lewin, dalam Rochiati 2006: 83).

Adapun Instrumen Penelitian yang digunakan adalah tes Metode tes ini merupakan tes tulis pilihan ganda sejumlah 20 butir soal. Menurut Suharsimi Arikunto (2007: 203), instrumen penelitian dapat diartikan sebagai alat atau fasilitas yang digunakan oleh peneliti dalam mengumpulkan data agar pekerjaannya lebih mudah dan hasilnya lebih baik, dalam arti lebih cermat, lengkap, dan sistematis, sehingga data yang diperoleh mudah untuk diolah. Dengan pengambilan data dilakukan metode tes melalui tes siklus 1 dan tes siklus 2. Yang pelaksanaannya pada akhir pertemuan ke 2

Berdasarkan data yang diperoleh, maka analisis data dilakukan dengan cara memadukan perolehan data secara keseluruhan. Langkah-langkah yang dilakukan peneliti dalam menganalisis data adalah sebagai berikut:

1) Menetapkan Pedoman Penilaian Tes

Data perolehan tes pilihan ganda siswa dipaparkan secara deskriptif untuk mengetahui peningkatan hasil belajar siswa. Dengan skor benar 1 dan slah 0. Selanjutnya skor dikonversikan menjadi nilai. Untuk mengubah skor menjadi nilai maka dilakukan konversi skor kedalam nilai atau $z$ skor yaitu nilai yang berskala 1 - 100 (Anas Sudijono, 2003:313) dengan menggunakan rumus konversi sebagai berikut:

$$
\mathrm{NA}=\frac{\sum \mathrm{S}}{\sum \mathrm{SM}} \mathrm{X} 100
$$

Keterangan :

$$
\begin{aligned}
\mathrm{NA} & =\text { Nilai akhir } \\
\sum \mathrm{S} & =\text { Jumlah Skor Siswa } \\
\sum \mathrm{SM} & =\text { Jumlah skor ideal (skor maksimal) } \\
100 & =\text { Standar nilai ideal. }
\end{aligned}
$$

Siswa dinyatakan tuntas apabila nilainya sama atau lebih 65. Bila nilai yang diraih dibawah 65 atau rentang 0-64 maka siswa tersebut dinyatakan tidak tuntas. Hal ini dikarenakan indikator ketuntasan siswa adalah 65 sesui dengan nilai KKM untuk KD 1.1 mendeskripsikan wilayan Indoensia adalah 65. Menentukan Nilai Rata-rata Perolehan

Tahap selanjutnya menentukan nilai rata-rata dalam satu kelas digunakan rumus sebagai berikut:

$$
M X=\frac{\sum N}{\sum S}
$$

Keterangan :

$$
\begin{aligned}
& \mathrm{MX}=\text { Nilai Rata-rata } \\
& \sum \mathrm{N}=\text { Jumlah Nilai } \\
& \sum \mathrm{S}=\text { Jumlah Siswa }
\end{aligned}
$$


Peneliti dan kolaborator juga menetapkan indikator pencapaian nilai rata-rata kelas. Untuk penelitian kali ini nilai rata-rata perolehan siswa dalam 1 kelas batas ketuntasannya disesuaikan dengan KKM mata pelajaran IPS yaitu 70. Apabila nilai ratarata yang diperoleh sama atau lebih 70 maka penelitian tindakan kelas dinyatakan berhasil. Tetapi apabila masih kurang dari 70 maka penelitian dinyatakan belum berhasil

Sedangkan untuk mengetahui presentasi ketuntasan klasikal, rumus yang digunakan adalah:

$$
\mathrm{P}=\frac{\sum \mathrm{T}}{\sum \mathrm{S}} \times 100
$$

Keterangan :

$\mathrm{P} \quad=$ Presentase Ketuntasan

$\sum \mathrm{T}=$ Jumlah Siswa Tuntas

$\sum \mathrm{S}=$ Jumlah Siwa seluruhnya

Prosentase ketuntasan ditetapkan adalah $80 \%$ artinya jumlah siswa yang melampaui KKM harus sama dengan atau melebihi $80 \%$ dari jumlah siswa. Bila tidak bisa mencapai $80 \%$ maka kegiatan penelitian belum berhasil.

\section{HASIL DAN PEMBAHASAN}

\section{Siklus 1}

Segera setelah pelaksanaan kegiatan siklus 2 berakhir, kolaborator dan peneliti melakukan kegiatan analisis. Dari hasil analisis pekerjaan siswa pada tindakan siklus 1 maka dapat diketahui bahwa ada peningkatan pada hasil belajar siswa pada materi mendeskripsikan wilayah dan penduduk. Misalnya jumlah yang berhasil memncapai KKM meningkat menjadi 24 siswa dari 32 atau $75.00 \%$. Sedangkan siswa yang tidak berhasil mencapai KKM berkurang menjadi 8 siswa atau 25,00\%. Begitu juga dengan nilai rata-rata kelas yang juga mengalami peningkatan dari 65,47 pada saat pra siklus menjadi 71,56 pada siklus 1.Secara lengkap hasil belajar siswa materi mendeskripsikan wilayah dan penduduk dapat diketahui dari tabel 1 berikut ini:

Tabel 1. Hasil Uji Kompetensi Siklus 1

\begin{tabular}{|c|c|c|c|c|c|c|c|}
\hline No & Nilai (N) & $\begin{array}{c}\text { Frek. } \\
\text { (F) }\end{array}$ & F X N & $\%$ & Keterangan & Jml & $\%$ \\
\hline 1 & 100 & 0 & 0 & 0,00 & Tuntas & \multirow{7}{*}{24} & \multirow{7}{*}{75,00} \\
\hline 2 & 95 & 1 & 95 & 3,13 & Tuntas & & \\
\hline 3 & 90 & 2 & 180 & 6,25 & Tuntas & & \\
\hline 4 & 85 & 3 & 255 & 9,38 & Tuntas & & \\
\hline 5 & 80 & 4 & 320 & 12,50 & Tuntas & & \\
\hline 6 & 75 & 4 & 300 & 12,50 & Tuntas & & \\
\hline 7 & 70 & 5 & 350 & 15,63 & Tuntas & & \\
\hline
\end{tabular}




\begin{tabular}{|c|c|c|c|c|c|c|c|}
\hline 8 & 65 & 5 & 325 & 15,63 & Tuntas & & \\
\hline 9 & 60 & 5 & 300 & 15,63 & Belum Tuntas & \multirow{3}{*}{8} & \multirow{3}{*}{25,00} \\
\hline 10 & 55 & 3 & 165 & 9,38 & Belum Tuntas & & \\
\hline 11 & 50 & 0 & 0 & 0,00 & Belum Tuntas & & \\
\hline \multicolumn{2}{|c|}{ Jumlah } & 32 & 2290 & 100,00 & & 32 & 100,0 \\
\hline \multicolumn{3}{|c|}{ Rata-rata } & 71,56 & & & & \\
\hline
\end{tabular}

Tabel di atas dapat diketahui perkembangan hasil belajar siswa kelas VIII A SMP negeri 2 Dongko setelah melakukan kegiatan pembelajaran dengan model " $G$ to $G$ Investigation". Walaupun sudah ada peningkatan setelah siklus 1, target peneliti bahwa nilai rata-rata kelas sudah melampaui target yang diharapkan yakni diatas 70, akan tetapi ketuntasan secara klasikal belum terpenuhi. Ketuntasan klasikal yang diharapkan adalah sama atau lebih $80 \%$. Untuk itu kolaborator dan peneliti memutuskan bahwa penelitian tindakan kelas belum berhasil dan dilanjutkan pada siklus 2

\section{Siklus 1}

Siklus 2 dilaksanakan sesuai rencana yakni Senin tanggal 9 Agustus 2010 dan hari Selasa tanggal 10 Agustus 2010. Peneliti dan kolaborator melakukan kegotan siklus 2 setelah mengadakan perbaikan-perbaikan berdasarkan masukan kolaborator. Dari pengamatan kolaborator tidak ada lagi kendala yang dihadapi oleh siswa kelas VIII A dalam kegiatan pembelajaran. begitu pula dengan hasil belajar yang sudah jauh meningkat dibandingkan dengan siklus 1 . Secara rinci hasil kegiatan siklus 2 dapat dilihat dari tabel 2 berikut ini.

Tabel 2. Hasil Uji Kompetensi Siklus 2

\begin{tabular}{|c|c|c|c|c|c|c|c|}
\hline No & $\begin{array}{l}\text { Nilai } \\
(\mathbf{N})\end{array}$ & $\begin{array}{c}\text { Frek. } \\
\text { (F) }\end{array}$ & F X N & $\%$ & Keterangan & Jml & $\%$ \\
\hline 1 & 100 & 1 & 100 & 3,13 & Tuntas & \multirow{8}{*}{29} & \multirow{8}{*}{90,63} \\
\hline 2 & 95 & 2 & 190 & 6,25 & Tuntas & & \\
\hline 3 & 90 & 4 & 360 & 12,50 & Tuntas & & \\
\hline 4 & 85 & 5 & 425 & 15,63 & Tuntas & & \\
\hline 5 & 80 & 6 & 480 & 18,75 & Tuntas & & \\
\hline 6 & 75 & 5 & 375 & 15,63 & Tuntas & & \\
\hline 7 & 70 & 2 & 140 & 6,25 & Tuntas & & \\
\hline 8 & 65 & 4 & 260 & 12,50 & Tuntas & & \\
\hline 9 & 60 & 3 & 180 & 9,38 & Belum Tuntas & \multirow{3}{*}{3} & \multirow{3}{*}{9,38} \\
\hline 10 & 55 & 0 & 0 & 0,00 & Belum Tuntas & & \\
\hline 11 & 50 & 0 & 0 & 0,00 & Belum Tuntas & & \\
\hline
\end{tabular}




\begin{tabular}{|c|c|c|c|c|c|c|}
\hline Jumlah & 32 & 2510 & 100,00 & & 32 & 100,0 \\
\hline \multicolumn{2}{|c|}{ Rata-rata } & 78,44 & & & & \\
\hline
\end{tabular}

Dari tabel diatas dapat disimpulkan bahwa telah terjadi peningkatan hasil belajar kelas VIII A SMP Negeri 2 Dongko semester 1. Peningkatan ini terjadi pada nilai ratarata kelas pada saat siklus 1 adalah 71,56, pada saat siklus 2 meningkat menjadi 78,44. Ketuntasan sudah melampaui target yang diharapkan yakni 90,63\%. Dengan demikian peneliti dan kolaborator menyimpulkan bahwa kegiatan penelitian dengan model " $\mathrm{G}$ to G Ivestigation" telah berhasil.

Apabila dikonversikan dalam bentuk tabel maka, perkembangan keberhasilan mereka dapat dilbaca dari grafik berikut ini

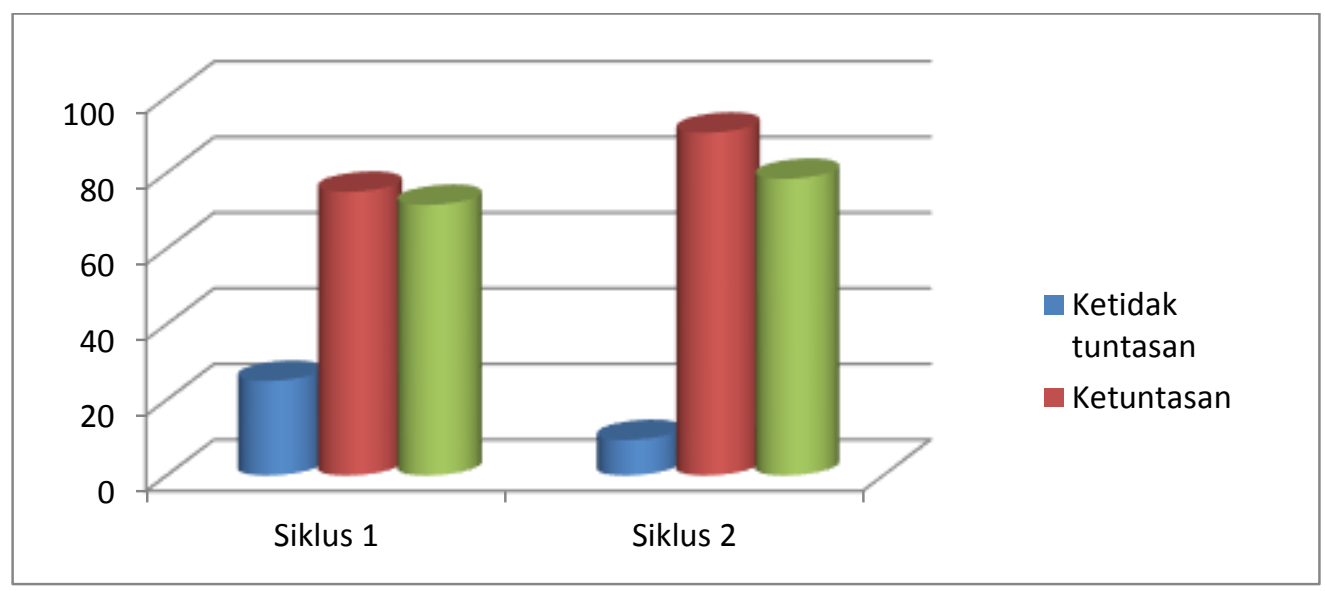

Grafik 1. Grafik Hasil Belajar siklus 1 dan siklus 2

Rentang prosentase siswa yang belum tuntas (warna biru) pada saat siklus 1 dan berkurang lagi menjadi $25,00 \%$ pada saat berkurang menjadi 9,38\% pada siklus 2 . Sedangkan persentase ketuntasan (warna merah tua) pada saat siklus 1 adalah $75.00 \%$ meningkat menjadi $90,63 \%$ pada saat siklus 2. Demikian pula dengan nilai rata-rata kelas VIII A (warna hijau) pada saat siklus 1 adalah 71,5 dan meningkat menjadi 78,44 pada siklus 2. Berdasarkan pembahasan dan simpulan di atas, peneliti menyarankan agar 1) Guru dapat berperan menjadi motivator serta dapat mengembangkan kreatifitas dalam kegiatan pembelajaran sehingga dapat meningkatkan hasil belajar siswanya 2) Guru hendaknya dapat menerapkan berbagai pendekatan dan model pembelajaran sehingga proses kegiatan pembelajaran yang dilakukan menejadi lebih variatif dan menyenangkan 3) Guru dapat mengunakan model pembelajaran "G to G Investigation" ini sebagai salah alternatif dalam mengatasi permasalahan yang muncul pada saat proses kegiatan pembelajaran

\section{KESIMPULAN DAN SARAN}

Dari hasil penelitian dapat diketahui peningkayan keberhasilan siswa, pada saat siklus 1 persentase ketuntasan adalah $75.00 \%$ meningkat menjadi 90,63\% pada saat 
siklus 2. Demikian pula dengan nilai rata-rata kelas VIII A pada saat siklus 1 adalah 71,5 dan meningkat menjadi 78,44 pada siklus 2 .

Berdasarkan pembahasan dan simpulan di atas, peneliti menyarankan agar 1) Guru dapat berperan menjadi motivator serta dapat mengembangkan kreatifitas dalam kegiatan pembelajaran sehingga dapat meningkatkan hasil belajar siswanya 2) Guru hendaknya dapat menerapkan berbagai pendekatan dan model pembelajaran sehingga proses kegiatan pembelajaran yang dilakukan menejadi lebih variatif dan menyenangkan 3) Guru dapat mengunakan model pembelajaran "G to G Investigation" ini sebagai salah alternatif dalam mengatasi permasalahan yang muncul pada saat proses kegiatan pembelajaran

\section{DAFTAR PUSTAKA}

Anas, Sudijono. 2003. Pengantar Evaluasi Pendidikan. Jakarta: PT. Raja Grafindo Persada, Cet. XII.

Arikunto, Suharsimi.2007. ProsedurPenelitian. Jakarta: Rineka Cipta.

Anderson, Neil. 2003. "Reading” dalam Practical English Language Teaching Reading. David Nunan (ed.). New York: McGraw Hall.

Brown, H. Douglas. 2003. Language Assessment: Principle and Classroom Practice.San Fransisco: Person Education Inc.

Depdiknas. 2004. Pendekatan Kontekstual: Contextual Teaching and Learning (CTL). Jakarta: Direktorat Jenderal Pendidikan Dasar dan Menengah Direktorat Pendidikan Lanjutan Pertama.

Hardjono, Surtinah. 1988. Prinsip-prinsip Pengajaran Bahasa dan Sastra. Jakarta:

Djamarah,Saiful Bahri. 1996. Prestasi Belajar dan Kompetensi Guru. Jakarta: Usaha Nasional. Depdikbud, Dirjen Dikti, PPLPTK.

Muhajir, Noeng. 1997. Metodologi Penelitian Kualitatif. Yogyakarta: tp

Ngalim Purwanto. 2002. Prinsip-prinsip dan Teknik Evaluasi Pengajaran. Bandung: Remaja Rosdakarya.

Nurhadi. 2002. Pendekatan Kontekstual (Contextual Teaching and Learning). Jakarta: Ditjen Dikdasmen Depdiknas.

Poerwadarminta, W.J.S. 2003. Kamus Umum Bahasa Indonesia. Jakarta: Balai Pustaka

Rochiati Wiriaatmadja. 2008. Metode Penelitian Tindakan Kelas untuk Meningkatkan Kinerja Guru dan Dosen. Bandung: Remaja Rosdakarya.

Rohman, Muhammad Nur et.al. 2009. Ilmu Pengetahuan Sosial Terpadu. Jakarta: Intan Pariwara

Slameto.2010. Belajar dan Faktor-Faktor yang Mempengaruhinya. Jakarta : Rineka Cipta.

Nana Sudjana. 2010. Dasar-dasar Proses Belajar Mengajar. Bandung: PT.Sinar Baru Algesindo.

Uno,Hamzah B. dan Nurdin Mohamad. 2011. Belajar dengan Pendekatan PAILKEM: Pembelajaran Aktif, Inovatif, Lingkungan, Kreatif, Efektif, Menarik . Jakarta: Bumi Aksara.

Widoyoko, Eko Putro S. 2009. Evaluasi Program Pembelajaran. Yogyakarta: Pustaka Pelajar. 